\title{
Change in number of rainy days in the municipality of Visconde de Mauá, Rio de Janeiro
}

\author{
André Cleber da S. Bunhak ${ }^{\mathrm{a}}$, Henderson Silva Wanderley ${ }^{a} *(\mathbb{0}$ \\ ${ }^{\text {a }}$ Forest Institute, Department of Environmental Sciences - Federal Rural University of Rio de Janeiro \\ *Autor correspondente (henderson@ufrrj.br)
}

\section{N F O}

\section{Keywords}

south fluminense

change climate

tend

student's t test
Palavras-chaves

sul fluminense

mudanças climáticas tendência

teste t de Student

\begin{abstract}
A B S T R A C T
Climate change has the potential to change the distribution of rainfall. However, for Sul Fluminense this analysis was not performed. Thus, the objective of this research was to identify changes in the number of rainy days in the South Fluminense region. Daily rainfall data from 1938-2011 were used for the study from a weather station located in the municipality of Visconde de Mauá-RJ. The rain data were divided into five classes of days with rain equal to: $\mathrm{P}=0 ; 0<\mathrm{P} \leq 5 ; 5>\mathrm{P} \leq 10 ; 10>\mathrm{P} \leq 15 ; 15>\mathrm{P} \leq 20$. The analysis was performed using the rain data for the months of January (summer) and July (winter). The rain classes were submitted to Student's $t$ test for the linear regression slope to identify possible changes in rainfall classes. For this test, a significance level of $5 \%$ was adopted. The analysis showed that the classes $5>\mathrm{P} \leq 10 ; 10>\mathrm{P} \leq 15 ; 15>\mathrm{P} \leq 20$ for the month of January, showed a reduction, but there was no statistical significance for the test applied. For January only classes $0<\mathrm{P} \leq 5$ showed an increase which statistically significant. In July there was an increase in classes $5>\mathrm{P} \leq 10$ and $10>\mathrm{P} \leq 15$ and reduction in $0<\mathrm{P} \leq 5$ and $15>\mathrm{P} \leq 20$. However, without statistical significance for July. Results show greater reduction the rainfall in January.
\end{abstract}

\section{R E S U M O}

Mudança no número de dias com chuva no município de Visconde de Mauá, Rio de Janeiro.

As mudanças climáticas têm o potencial de modificando a distribuição das chuvas. No entanto, para o Sul Fluminense essa análise não foi realizada. Assim, o objetivo desta pesquisa foi identificar mudança no número de dias com chuva na região Sul Fluminense. Para o estudo foram utilizados dados diários de chuva entre 1938-2011, proveniente de uma estação meteorológica localizada no municio de Visconde de Mauá-RJ. Os dados foram subdivididos em cinco classes de dias com chuva igual a: $\mathrm{P}=0 ; 0<\mathrm{P} \leq 5 ; 5>$ $\mathrm{P} \leq 10 ; 10>\mathrm{P} \leq 15 ; 15>\mathrm{P} \leq 20$. A análise foi realizada para os meses de janeiro (verão) e julho (inverno). As classes foram submetidas ao teste $t$ de Student para o coeficiente angular da regressão linear, para identificar possível alteração nas classes de chuva. Para esse teste, foi adotado nível de significância de $5 \%$. A análise mostrou que as classes $5>\mathrm{P} \leq 10 ; 10>\mathrm{P} \leq 15 ; 15>\mathrm{P} \leq 20$, para o mês janeiro, apresentou redução, mas sem significância estatística. Para janeiro, apenas a classe $0<\mathrm{P} \leq 5$ apresentou aumento, sendo esse com significância estatística. No mês de julho foi observado aumento nas classes $5>\mathrm{P} \leq 10 \mathrm{e}$ $10>\mathrm{P} \leq 15$, e redução para $0<\mathrm{P} \leq 5$ e $15>\mathrm{P} \leq 20$. No entanto, sem significância estatística para julho. Os resultados indicam redução maior das chuvas para o mês de janeiro. 


\section{INTRODUCTION}

Water is a renewable natural resource of fundamental for the conservation and balance of biodiversity and maintenance of life on the planet, which is renewed naturally in the hydrological cycle. However, the rainfall regime may change due to changes in the climate, which can compromise the water availability of a region and its agriculture. Another relevant aspect due to the change in rainfall is the increase in the number of days without rain, which can be crucial for storage of water in reservoirs and power generation.

According to Qian and Lin (2005) the frequency and persistence of droughts should be one of the consequences of global warming, change in land use and urban growth. Thus, knowledge about changes in the rainfall regime of a region, as a result of climate change, is essential for the development of public administrations that will lead to actions on the management of water resources and make it possible to mitigate their impacts on agriculture and the environment (Wanderley et al., 2013).

The temperature increase and deforestation has the potential to interfere with the rainfall regime, changing the distribution of rainfall mainly due to the intensification of the hydrological cycle, where this change is related to the intensity, frequency and distribution of rain. The distribution of rainfall has shown a change in various locations on the planet, with an increase in extreme events.

To understand this change indices for climate variability and extremes have been used for a long time, often by assessing days with temperature or precipitation observations above or below specific physically-based thresholds (Zhang et al., 2011). Halimatou et al. (2017) identified results of precipitation extremes for Ségou showed positive significant decrease in consecutive wet day and in extremely wet, whereas Maximum 5 day's precipitation showed positive insignificant increase and the total annual precipitation showed a positive insignificant decrease. Shi et al. (2018) showed that the spatial trends of consecutive dry days and consecutive wet days were significant only in several regions of China. Shau et al. (2019) showed that most of extreme precipitation indices decreased in spring, autumn and winter, and increased in summer, whereas consecutive dry days increased in all seasons. At the monthly scales, wet precipitation extremes mostly occurred in July, and upward trends of extreme precipitation events dominated in February, June, July and August.

For some regions of Brazil change in precipitation was identified with a statistically significant trend (Wanderley et al., 2013; Obregón et al., 2014). In some cases there is a change in precipitation and temperature (Salviano et al.,
2016; Wanderley et al., 2014). For the state of Rio de Janeiro Wanderley and Bunhak (2016) identified changes in the number of rainy days.

Therefore, there is a need to evaluate and quantify the main changes presented by the daily distribution of rainfall, identifying whether these changes can already be a response to climate change. Thus, the objective of this research was to identify changes in the number of rainy days in the South Fluminense region.

\section{MATERIAL AND METHODS}

Daily rainfall data from 1938-2011 were used for the study from a weather station $\left(-22,33^{\circ},-44,54^{\circ}\right.$, $11220,62 \mathrm{~m})$ located in the municipality of Visconde de Mauá-RJ, located in the southern region of the state of Rio de Janeiro (Figure 1). The Visconde de Mauá region is on the border between the states of Rio de Janeiro, Minas Gerais and São Paulo in an environmental protection area at the top of the Serra da Mantiqueira on the border with the Itatiaia National Park.

The precipitation data were divided into five classes of rain (mm): class $-1 \mathrm{P}=0$; class $-20<\mathrm{P} \leq$ 5; class-3 $5>\mathrm{P} \leq 10$; class- $410>\mathrm{P} \leq 15$ and class$515>\mathrm{P} \leq 20$. The analysis was carried out for the months of January (summer) and July (winter). These months were selected because the state of Rio de Janeiro has about $70 \%$ to $80 \%$ of rainfall in the summer months and $20 \%$ to $30 \%$ in winter, based on the months of January and July, which are two extremes of rain, since January is part of the months with the highest rainfall (summer) and July is part of the months with the lowest rainfall (winter) (André et al., 2008).

The rain data was counted in the total of days for each class. The total number of days presented by the rain classes was submitted to regression analysis performed using the Student's t test of significance for the slope of the line. This test was used to assess whether the slope of the $\beta$ line is significantly different from zero, indicating the presence of a change in the time series (trend), considering the linear regression of $\mathrm{Y}$ with a random variable in time $\mathrm{X}$, Eq. (1).

$$
\mathrm{Y}=\alpha+\beta \mathrm{X}
$$

where:

$$
\begin{aligned}
& Y \text { - variable under analysis } \\
& X \text { - time } \\
& \alpha \text { and } \beta-\text { regression coefficients } \\
& \text { calculated by the least squares method. }
\end{aligned}
$$




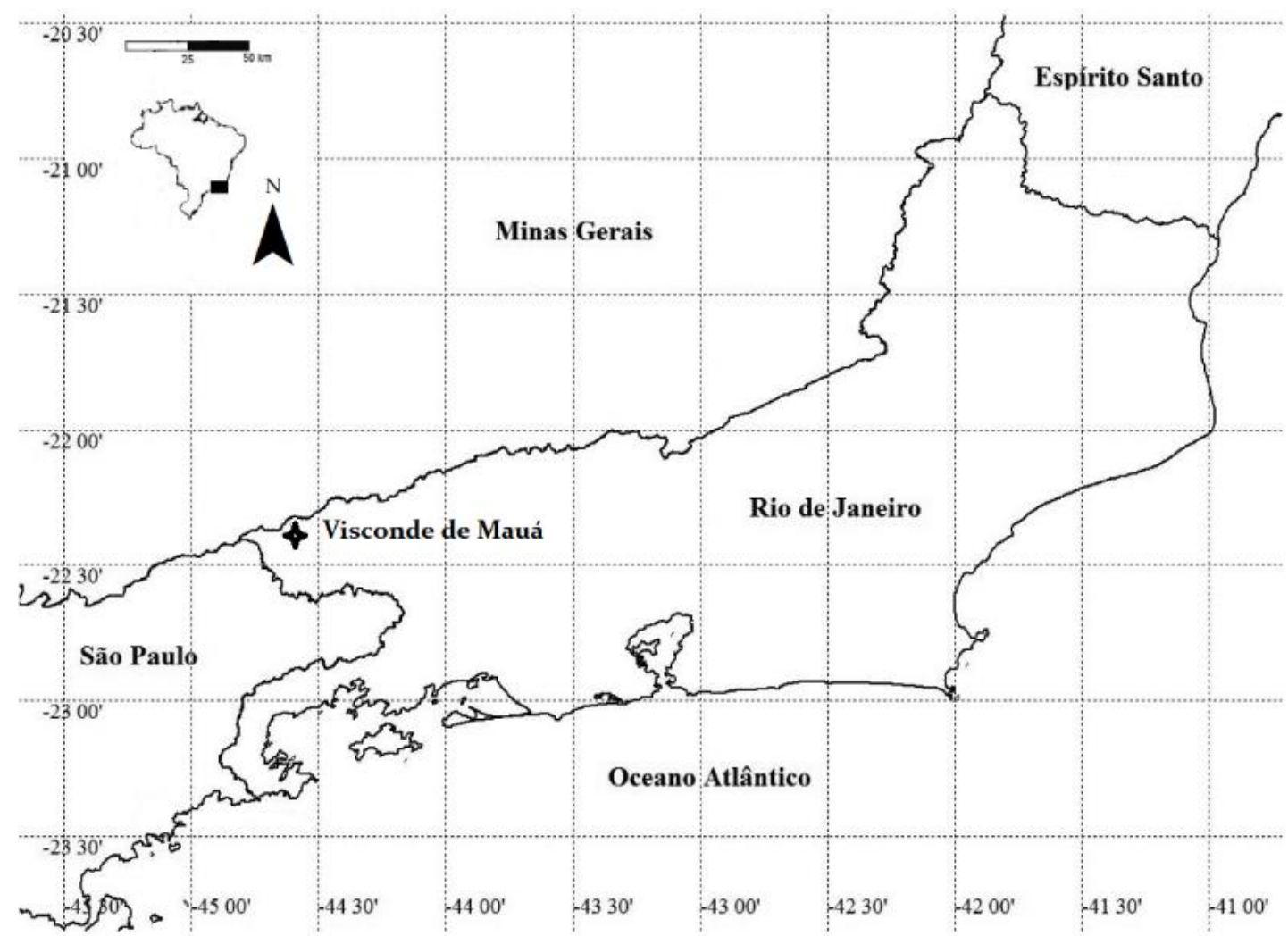

Figure 1 - Identification of the study site.

The null hypothesis (Ho) that there is no change, that is, $\beta=0$, was tested using Student's $t$ test with $\mathrm{n}$-2 degrees of freedom, Eq. (2). The hypothesis that there is no change is rejected when the calculated $t$ value is greater, in absolute value, than the critical value $t \alpha / 2, n-2$, tabulated, at a certain level of significance $\alpha o$, with a level adopted for this test significance of $5 \%$.

$$
t=\frac{r \sqrt{n-2}}{\sqrt{1-r^{2}}}=\frac{b}{s / \sqrt{S S x}}
$$

where:

$\mathrm{n}$ - sample size

$r$ - Pearson's correlation coefficient

$\mathrm{s}$ - standard deviation of residues

b - slope of the rectum

SSX - sum of squares of the independent variable (time in trend analysis).

\section{RESULTS AND DISCUSSION}

The results obtained for the daily rain classes show a negative trend for almost all the classes analyzed for the month of January (Table 1). For this month, the class that indicates days without rain $\mathrm{P}$ $=0$, shows a reduction, indicating that there is an increase in rainy days this month. The linear adjustment ratifies the reduction by presenting an adjustment of the negative coefficient (Figure 2a). However, the reduction in class- $1 \mathrm{P}=0$ was not statistically significant. The reduction in days without rain for the month of January may be relevant, as this is the month with the highest rainfall for the state of Rio de Janeiro, which may indicate greater water availability or increased rainfall extremes.

Table 1 - Values of Student's t test applied to daily rain classes.

\begin{tabular}{lccccc}
\hline \multicolumn{7}{c}{ Months } & \multicolumn{5}{c}{ Rain Classes } \\
\hline & $\mathrm{P}=0$ & $0<\mathrm{P} \leq 5$ & $5>\mathrm{P} \leq 10$ & $10>\mathrm{P} \leq 15$ & $15>\mathrm{P} \leq 20$ \\
\hline January & $-0,444$ & $2,459^{*}$ & $-0,918$ & $-0,724$ & $-1,211$ \\
July & 0,083 & $-0,397$ & 0,554 & 0,868 & $-1,320$ \\
\hline
\end{tabular}

* Statistically significant. 

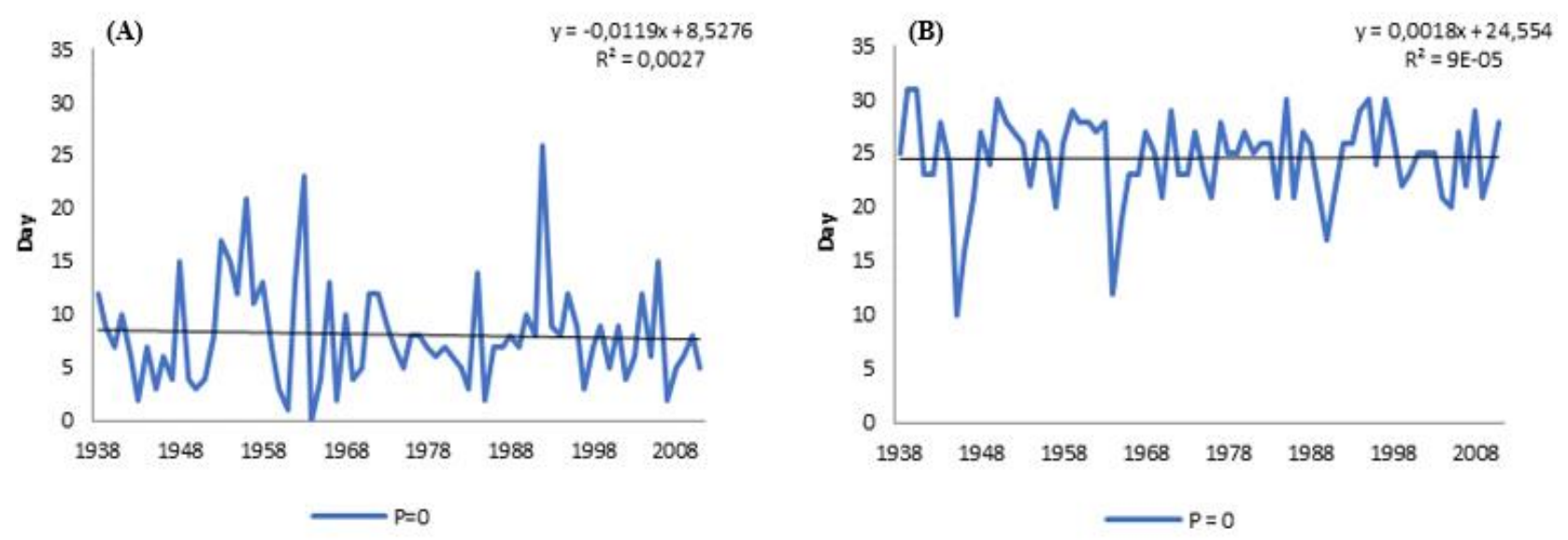

Figure 2 - Linear regression for rain class $\mathrm{P}=0$ : a) January and b) July.

The month of July shows a tendency to increase the days without rain of class-1. the linear adjustment for July shows a small positive increase in its coefficient (Figure 2b). However, without statistical significance. The increase to class-1 $\mathrm{P}=$ 0 in July may indicate a reduction in rainfall in a month of greater water deficit in the state of Rio, making water supply and agricultural practices in the region even more unavailable.

For class-2 $0<\mathrm{P} \leq 5$, an increase with statistical significance for the month of January and a

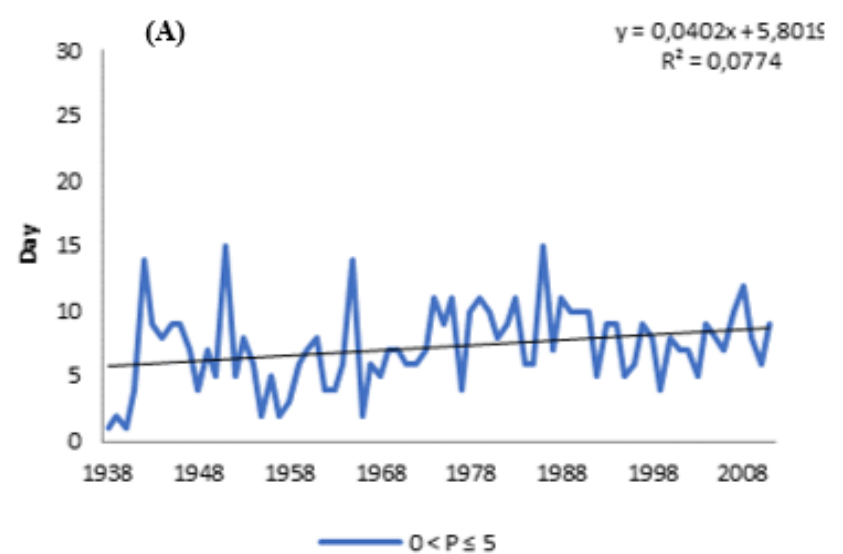

reduction for the month of July are observed. The linear adjustment for January shows a small positive increase in its coefficient and a change of 4 days per century (Figure 3a). The increase in rain in class-2 in January is not relevant, as part of this precipitation evaporates, as it is less intercity. This precipitation does not allow for hydraulic replacement and does not cause economic damage due to the occurrence of erosion, runoff, floods, landslide, among others.

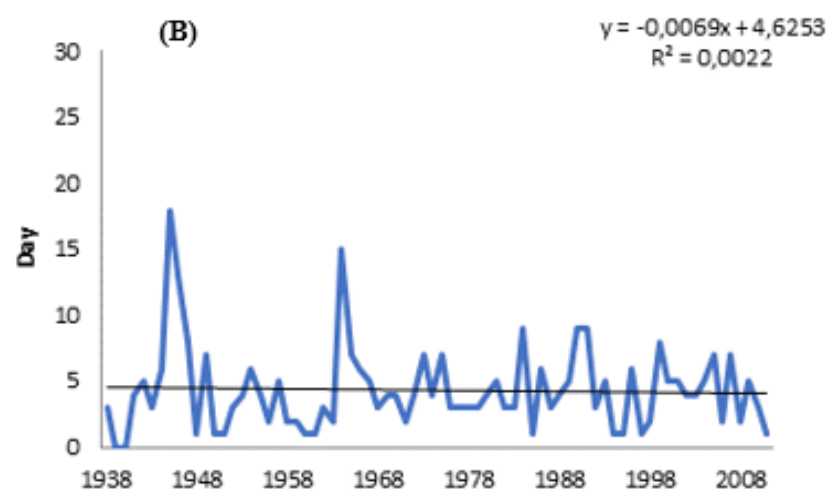

Figure 3 - Linear regression for rain class $0<\mathrm{P} \leq 5$ : a) January and b) July.

In July, the class 2 trend was reduced (Figure $3 b)$. The reduction of this and any other precipitation may be relevant, since the month of June is the month of the largest water deficit in the state of Rio de Janeiro.

Classes $5>\mathrm{P} \leq 10$ and $10>\mathrm{P} \leq 15$ for the month of January showed a reduction in the days with these pluviometric indices, although they did not present statistical significance for the applied test (Figures 4 and 5). The reduction in days with this class may be relevant if the change persists, as these rains are the most common during this month and contribute to the storage of water in the soil. 

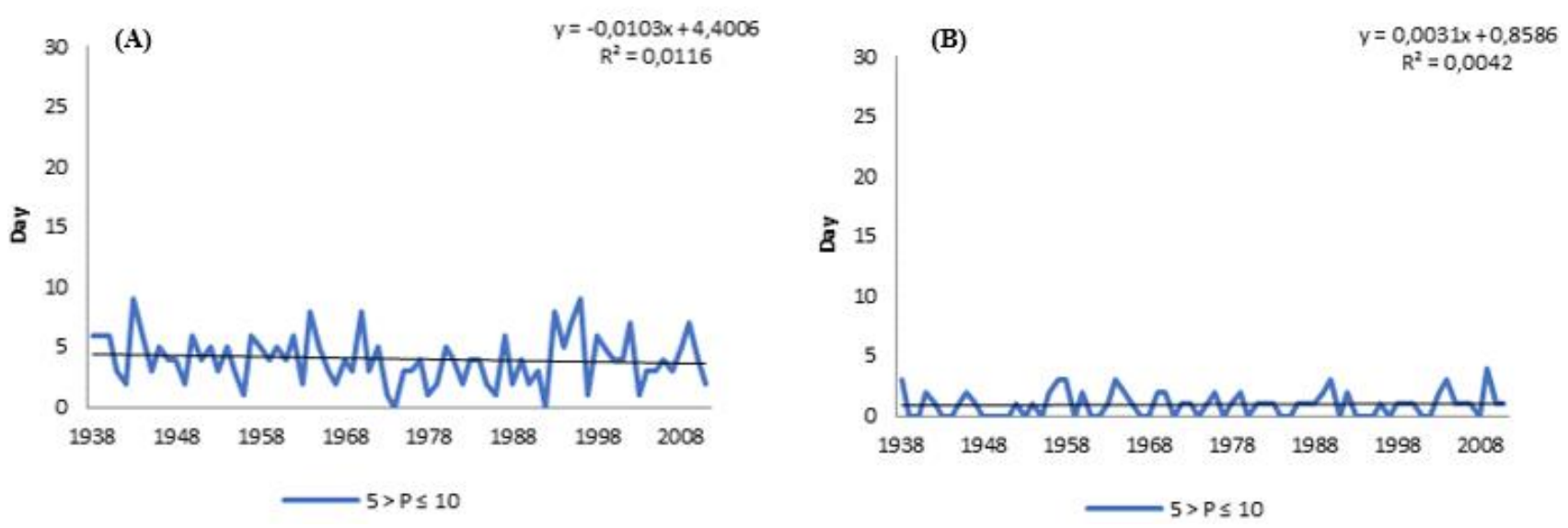

Figure 4 - Linear regression for rain class $5>P \leq 10$ : a) January and b) July.
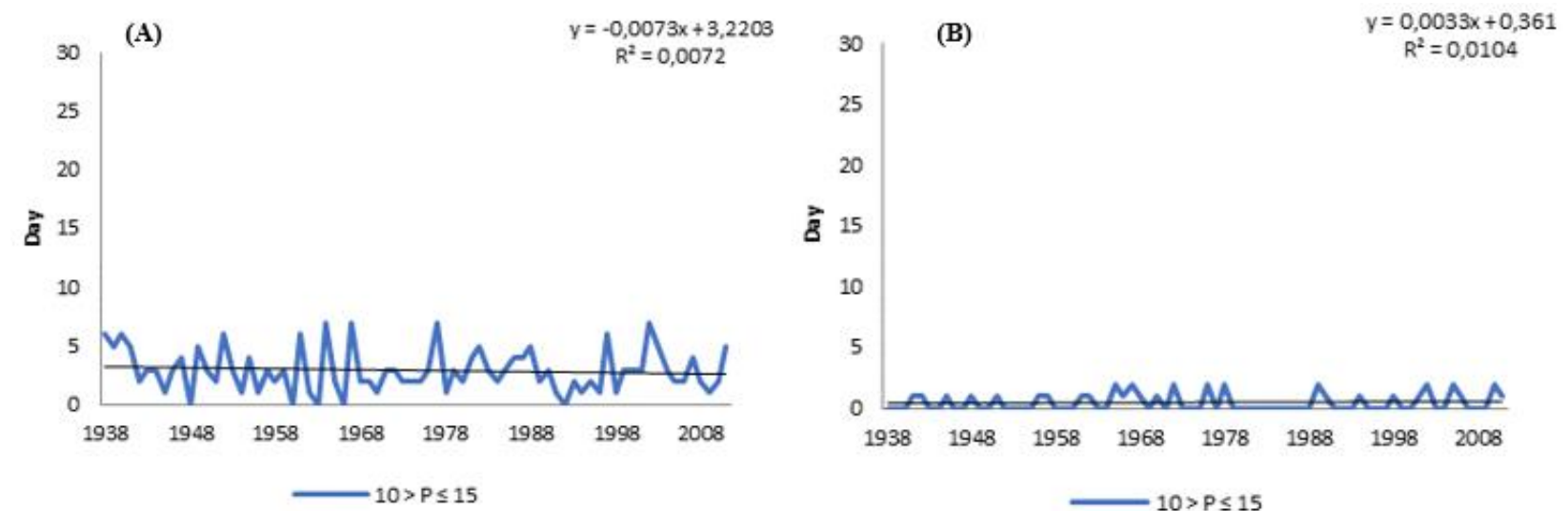

Figure 5 - Linear regression for rain class $10>\mathrm{P} \leq 15$ : a) January and b) July.

The trends obtained for the month of July are opposite to January for class-3 $5>\mathrm{P} \leq 10$ and class$410>\mathrm{P} \leq 15$. The class- 3 and class- 4 in july are the only ones that show increased rainfall for that month. The class- 3 and class- 4 increase is essential to contribute to the increase in rainfall in that month. According Sobral et al. (2018) the average rainfall for the month of June is $33 \mathrm{~mm}$. Similar to the other classes analyzed for the month of July, there was no statistical significance for these classes.

Climate projections for future climate indicated changes in availability for the region under analysis due to the may increase of more than $2{ }^{\circ} \mathrm{C}$ in the air temperature. There was practically no change in total rainfall annual, although rainfall variability has changed. Changing the distribution of rains, associated with the increase in temperature, cause disturbance in the availability water through change in evapotranspiration, surplus and water deficiency (Costa and Wanderley, 2019).

The class-5 $15>\mathrm{P} \leq 20$ is the only one in which the trend for the months of January and July was the same, both for reduction (Figure 6a). The analysis shows that for January the reduction in rainfall was found in classes 1, 3, 4 and 5. However, class-1 indicates increased rainfall for January, which may indicate an increase in extreme rainfall in the region under analysis. The extreme rainfall can have great impacts on society due to its possible cause floods and mass movement. The reduction change in class $15>\mathrm{P} \leq 20$ for July although without statistical significance it is observed from 1984 onwards only two events with rainfall (Figure $6 a)$. 

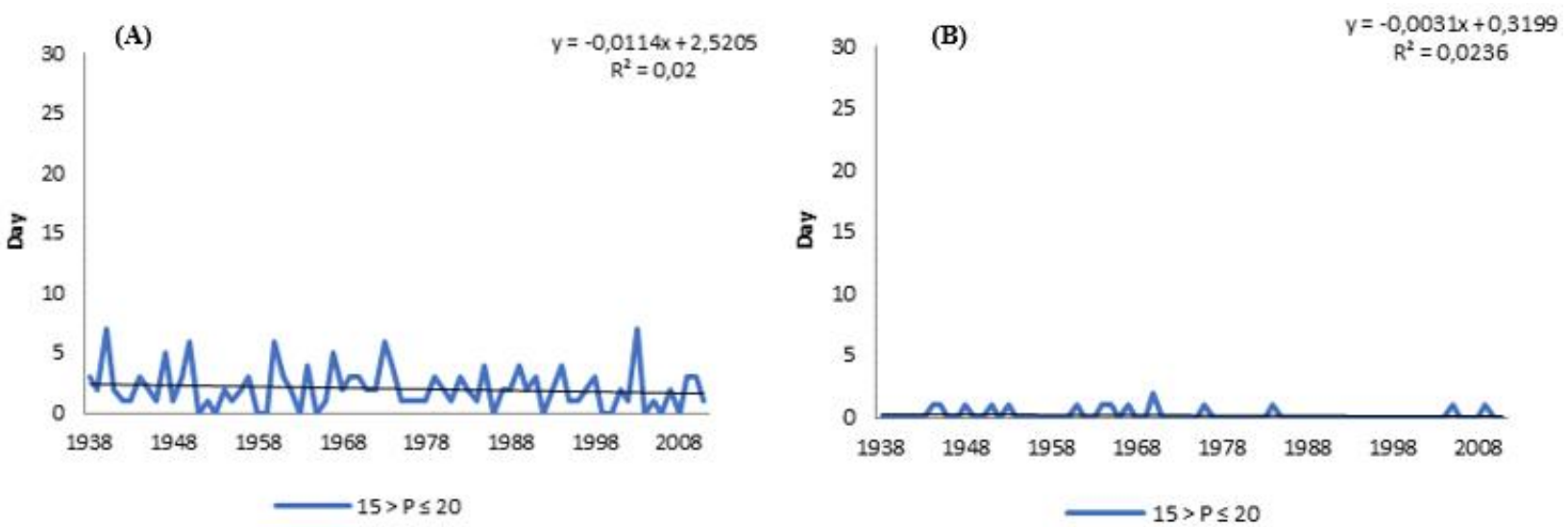

Figure 6 - Linear regression for rain class $15>\mathrm{P} \leq 20$ : a) January and b) July.

There is a discussion as to whether the changes already observed in the distribution of rain such as the increase in the frequency of extreme events are the result of changes in the climate, (Pendergrass and Hartmann, 2014). However, there is no consensus as to whether less intercity events will be less frequent (Chou et al., 2012 and Lau et al., 2013) as noted in this analysis.

Simulations of global climate models by Costa and Wanderley (2019) show a reduction in rainfall from January to March in the region and a deficit of water in the soil between May and August. There was also a reduction in the frequency of wet days and an increase in the intensity of rain (Sun et al., 2007). But there is agreement that the frequency of light rain events increases or decreases, as observed in studies of Chou et al. (2012) and Lau et al. (2013).

\section{CONCLUSIONS}

The distribution of rain analyzed for the months of January and July although no statistical significance is presented for all classes. For the month of January, the reduction can be observed in all rain classes. In the month of July there is an increase in rainy days for classes $5>\mathrm{P} \leq 10$ and 10 $>\mathrm{P} \leq 15$, and reduction for classes $0<\mathrm{P} \leq 5$ and 15 $>\mathrm{P} \leq 20$. However, there was no statistical significance for the month of July. This reduction can cause significant impacts on the use of water for urban and agricultural supply, as it is an important month for the region under analysis.

\section{ACKNOWLEDGMENT}

The Federal Rural University of Rio de Janeiro (UFRRJ), for financing this research through the granting of a Scientific Initiation scholarship. And the institution linked to the following approved project: Fundação Carlos Chagas Filho de Amparo à Pesquisa do Estado do Rio de Janeiro (FAPERJ).

\section{REFERÊNCIAS BIBLIOGRÁFICAS}

Andre RGB, Marques VS, Pinheiro FMA, Ferraudo AS. Identificação de regiões pluviometricamente homogêneas no estado do Rio de Janeiro, utilizando-se valores mensais. Revista Brasileira de Meteorologia, v.23, n.4, p.501-509, 2008.http://dx.doi.org/10.1590/S010277862008000400009

Chou CC, Chen A, Tan PH, Chen T. Mechanisms for global warming impacts on precipitation frequency and intensity. Journal Climate, v.25, p.3291-3306, 2012. https://doi.org/10.1175/JCLI-D-11-00239.1

Costa GR, Wanderley HS. Projeção futura do balanco hídrico climatológico para mesorregião sul do estado do Rio de Janeiro. Ensaios nas ciências agrárias e ambientais. Atena Editora, 144-149p. 2019. DOI 10.22533/at.ed.414191601

Halimatou, T.; Kalifa, AT.; Baffour, KN. Assessment of changing trends of daily precipitation and temperature extremes in Bamako and Ségou in Mali from 1961- 2014. Weather and Climate Extremes, v.18, p.8-16, 2017. https://doi.org/10.1016/j.wace.2017.09.002

Lau WKM, Wu HT, Kim KM. A canonical response of precipitation characteristics to global warming from CMIP5 models. Geophysical Research Letters, v.40, p.3163-3169, 2013. https://doi.org/10.1002/grl.50420

Obregón G, Marengo J, Nobre C. Rainfall and climate variability: long-term trends in the Metropolitan Area of São Paulo in the 20th century. Climate Research, v.61, n.2, p.93107, 2014.

Pendergrass AG, Hartmann DL, Mudanças na distribuição da frequência e intensidade da chuva em resposta ao aquecimento global. Journal Climate. v.27, p.8372-8383, 2014. https://doi.org/10.1175/JCLI-D-14-00183.1

Qian W, Lin X. Regional trends in recent precipitation indices in China. Meteorology and Atmospheric Physics, v.90, p.193-207, 2005. https://doi.org/10.1007/s00703-004-0101$\mathrm{z}$

Salviano MF, Groppo JD, Pellegrino GQ. Análise de tendências em dados de precipitação e temperatura no Brasil. 
Revista Brasileira de Meteorologia, v.31, n.1, p.64-73, 2016. http://dx.doi.org/10.1590/0102-778620150003

Shao Y, Mu X, He Y, Sun W, Zhao G, Gao P. Spatiotemporal variations of extreme precipitation events at multi-time scales in the Qinling-Daba mountains region, China. Quaternary International, v.525, p.89-102. 2019. https://doi.org/10.1016/j.quaint.2019.07.029

Shi J, Cui L, Wen K, Tian Z, Wei P, Zhang B. Trends in the consecutive days of temperature and precipitation extremes in China during 1961-2015. Environmental Research, v.161, p.381-391. 2018. https://doi.org/10.1016/j.envres.2017.11.037

Sobral BS, Oliveira-Júnior JF, Gois G, Terassi PMB, MunizJúnior JGR. Variabilidade espaço-temporal e interanual da chuva no estado do Rio de Janeiro. Revista Brasileira de Climatologia. v.22, p,281-308, 2018.

Sun,Y.; Solomon, S.; Dai, A.; Portmann, RW. How often will it rain? Journal Climate, v.20, p4801-4818, 2007. https://doi.org/10.1175/JCLI4263.1

Wanderley HS. Sediyama GC, Justino FB, Alrncar LP, Delgado RC. Variabilidade da precipitação no Sertão do São Francisco, estado de Alagoas. Revista Brasileira de Engenharia Agrícola e Ambiental, v.17, n.7, p.790-795, 2013. https://doi.org/10.1590/S1415-43662013000700014

Wanderley HS, Carvalho AL, Fernandes RC, Souza JL. Mudança no regime temporal da temperatura do ar e precipitação pluviométrica na região de rio Largo, Alagoas. Revista Brasileira de Geografia Física, v.7, n.4, p.662-667, 2014. https://doi.org/10.26848/rbgf.v7.4.p662-667

Wanderley HS, Bunhak ACS. Alteration in precipitation and number of days without rain in the southern region of Rio de Janeiro state. Revista Brasileira de Geografia Física, v.9, n.7, p.2341-2353, 2016. https://doi.org/10.5935/19842295.20160167

Zhang X, Alexander L, Hegerl GC, Jones P, Tank AK, Peterson TC, Trewin B, Zwiers FW. Indices for monitoring changes in extremes based on daily temperature and precipitation data. WIREs Climate Change, v.2, n.6, p.851870, 2011. https://doi.org/10.1002/wcc.147 